\title{
Peningkatan Produktivitas Peternak Sapi Perah Melalui Penerapan Teknologi Inkubator Fermentasi Susu Penghasil Yogurt di Kecamatan Licin Kabupaten Banyuwangi
}

\author{
Endi Sailul Haq ${ }^{\# 1}$, Farisqi Panduardi ${ }^{* 2}$, Asmaul Khusna ${ }^{\# 3}$ \\ 1,2 Program Studi Teknik Informatika, Politeknik Negeri Banyuwangi \\ Jl. Raya Jember KM13 Labanasem, Kabat, Banyuwangi \\ lendiepoliwangi.ac.id \\ 2akufarisqiepoliwangi.ac.id \\ ${ }^{3}$ Program Studi Teknologi Pengolahan Hasil Ternak, Politeknik Negeri Banyuwangi \\ Jl. Raya Jember KM13 Labanasem, Kabat, Banyuwangi \\ 3akhusna@poliwangi.ac.id
}

\begin{abstract}
Mayoritas pencaharian penduduk di Desa Tamansari Kecamatan Licin, Kabupaten banyuwangi berprofesi sebagai perternak sapi perah. Dari hasil survey dan wawancara yang dilakukan pada pengelola kelompok ternak ini didapatkan data hasil perah susu per hari sebanyak 5.227 liter. Dengan jumlah perahan pada pagi hari sebanyak 3.113 liter dan sore hari sebanyak 2.054 liter. Dengan potensi rata - rata per peternak sebesar 90 liter/hari. hasil susu sapi perah yang diproduksi, dipasarkan ke PT. Nestle dan sisanya dikonsumsi masyarakat sekitar, dan penjualan susu sapi perah hanya terbatas di koperasi desa sehingga distribusi penjualan dan pemasaran hanya tersentral di daerah tersebut dan menyebabkan distribusi penjualan belum bisa merata ke daerah lain. Di samping itu Seluruh peternak hanya menjual susu sapi dalam keadaan segar. Dan ini menjadi keluhan bagi para produsen (peternak) dimana tingginya persaingan pemasaran susu sapi segar menyebabkan sulitnya pemasaran produk tersebut ditambah lagi produk tersebut mudah rusak (tidak tahan lama). Sulitnya pemasaran susu sapi segar karena tidak semua konsumen penyuka susu menyukai susu dalam keadaan segar karena rasa yang masih plain dan juga aroma yang lebih khas. Untuk itu kegiatan ini bertujuan untuk merancang dan membuat inkubator fermentasi susu untuk menghasilkan yogurt dan memberikan workshop terkait cara kerja, dan perawatan inkubator tersebut serta pengemasan dan pemasaran dari hasil produksi yogurt yang lebih luas dan lebih bernilai ekonomis tinggi. Kontribusi yang paling mendasar jika teknologi ini diterapkan adalah Inkubator fermentasi susu ini dapat menghasilkan yogurt yang berkualitas. Yogurt yang memiliki rasa, tekstur, aroma dan warna yang konsisten melalui proses pembuatan yang lebih efektif, efisien dan kapasitas produksi yang lebih tinggi karena prosesnya menggunakan inkubator yang telah dilengkapi dengan sistem kontrol dan monitoring yang terintegrasi. Serta memberikan keterampilan terhadap mitra dalam memproduksi dan memasarkan yogurt secara mandiri dan berkesinambungan dengan target pemasaran yang lebih luas.
\end{abstract}

Keywords - Peternak sapi perah, Inkubator susu, kontrol dan monitoring, yoghurt.

\section{Pendahuluan}

Kabupaten Banyuwangi memiliki luas wilayah 5.782,50 km. Banyuwangi masih merupakan daerah kawasan hutan karena besaran wilayah yang termasuk kawasan hutan lebih banyak kalau dibandingkan kawasan kawasan lainnya. Area kawasan hutan mencapai 183.396,34 ha atau sekitar 31,62\%; daerah persawahan sekitar 66.152 ha atau $11,44 \%$; perkebunan dengan luas sekitar $82.143,63$ ha atau $14,21 \%$; sedangkan yang dimanfaatkan sebagai daerah permukiman mencapai luas sekitar $127.454,22$ ha atau $22,04 \%$. Sisanya telah dipergunakan oleh penduduk Kabupaten Banyuwangi dengan berbagai manfaat yang ada, seperti jalan, ladang dan lain-lainnya. Selain penggunaan luas daerah yang demikian itu, Kabupaten Banyuwangi memiliki panjang garis pantai sekitar $175,8 \mathrm{~km}$, serta jumlah Pulau ada 13 buah. Seluruh wilayah tersebut telah memberikan manfaat besar bagi kemajuan ekonomi penduduk Kabupaten Banyuwangi.

Secara geografis Kabupaten Banyuwangi terletak di ujung timur Pulau Jawa. Wilayah daratannya terdiri atas dataran tinggi berupa pegunungan yang merupakan daerah penghasil produk perkebunan; dan dataran rendah dengan berbagai potensi produk hasil pertanian serta daerah sekitar garis pantai yang membujur dari arah utara ke selatan yang merupakan daerah penghasil berbagai biota laut. Kecamatan Licin merupakan kecamatan yang dikembangkan 
berdasarkan potensi dan arahan pengembangan di cluster Banyuwangi Utara di mana fungsi kegiatannya berkisar pada beberapa sector. Salah satu sector yang dikembangkan adalah peternakan sapi perah.

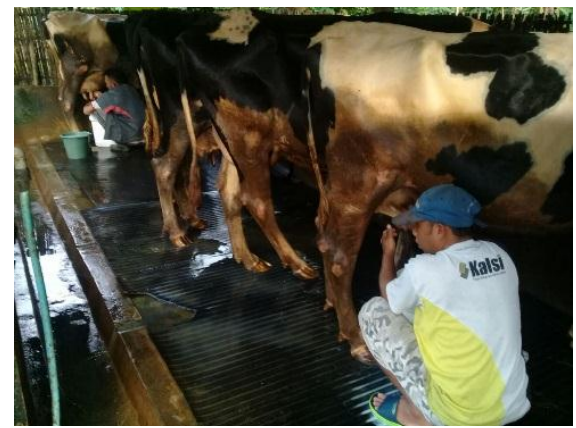

Gambar 1 Proses Pemerahan Susu Oleh Peternak "Ijen Makmur"

Saat ini pengembangan sapi perah sebagai salah satu komoditas unggulan sub sektor peternakan yang perlu mendapat perhatian serius di Kabupaten Banyuwangi, mengingat permintaan akan protein hewani baik daging, telur dan susu belum semuanya dapat dipenuhi oleh produksi dalam negeri. Untuk memenuhi kekurangan tersebut secara nasional, pemerintah mengimpor daging, susu maupun sapi dari luar negeri

\section{Permasalahan Mitra}

Potensi produksi susu sapi di Desa Tamansari Kecamatan Licin ini cukup besar tetapi seluruh peternak hanya menjual susu sapi dalam keadaan segar. Dan ini menjadi keluhan bagi para produsen (peternak) dimana tingginya persaingan pemasaran susu sapi segar menyebabkan sulitnya pemasaran produk tersebut ditambah lagi produk tersebut mudah rusak (tidak tahan lama). Sulitnya pemasaran susu sapi segar karena tidak semua konsumen penyuka susu menyukai susu dalam keadaan segar karena rasa yang masih plain dan juga aroma yang lebih khas.

Tingginya persaingan pemasaran yang dirasakan mitra dalam menjual susu sapi segar di daerahnya menyebabkan terkadang susu sapi segar tersebut tidak seluruhnya terjual habis sehingga sisa dari susu tersebut biasanya dikonsumsisendiri oleh peternak dan keluarganya. Malah tidak jarang karena sisa susu tersebut apabila tidak laku mereka buang. Disisi lain mitra juga mengeluhkan harga susu yang rendah, hanya bias menutupi biaya produksi dan sedikit keuntungan. Hal ini dapat disebabkan karena produk susu yang diolah masih kalah bersaing dengan produk susu keluaran industri susu modern yang beredar di berbagai daerah.

Ini terlihat dari kehidupan social ekonomi peternak yang masih dalam kategori sangat sederhana. Untuk itu tim mencoba membantu mencarikan solusi terhadap permasalahan yang dialami oleh mitra dengan mentransfer tekhnologi pengolahan susu menjadi yoghurt (susu fermentasi) yang kaya akan rasa, manfaat dan juga daya simpan yang lebih lama. Harga jual produk yang lebih tinggi dengan keuntungan pemasaran yang lebih tinggi.

Yoghurt dibuat dengan proses fermentasi antara susu segar dan bakteri asam laktat. Manfaat yoghurt sangat banyak diantaranya menjaga system pencernaan dalam tubuh, menangkal berbagai jenis penyakit seperti alergi, diare, tumor, kulit dan meningkatkan kekebalan tubuh. Tak hanya itu saja kandungan vitamin dalam yoghurt seperti vitamin A, B3, B12 dapat menjaga kulit wajah dari penuaan dini, dan juga bisa sebagai diet dalam penurunan berat badan. Karena kandungan yang terdapat dalam yoghurt ini banyak dijadikan sebagai peluang usaha yang sangat menjanjikan keuntungan. Yoghurt ini sangat disukai baik kalangan orang dewasa maupun anak-anak sehingga pemasarannya juga relative mudah yaitu bisa dilakukan disekitar lingkungan rumah, sekolah, arena permainan, tempat wisata ataupun taman kota. Yoghurt agar lebih tahan lama harus disimpan dalam lemari pendingin atau freezer. Dengan penyimpanan yang tepat yoghurt akan terjaga kwalitasnya dan tetap segar.

Pengolahan susu sapi perah menjadi yoghurt ditujukan untuk menganekaragamkan produk dan selera, di samping tujuan utamanya yaitu mengawetkan susu agar relatif lebih tahan lama bila disimpan. Produk olahan susu ni dapat memberikan dampak positif dalam kesehatan dan secara ekonomis data meningkatkan nilai jual susu dan dapat meningkatkan pendapatan masyarakat.

\section{SOLUSI DAN TARGET LUARAN}

\section{A. Solusi yang Ditawarkan}

Dari berbagai masalah yang dihadapi oleh Mitra tersebut maka disimpulkan pendekatan atau solusi yang ditawarkan adalah dalam usaha pembuatan yogurt dan meningkatkan perekonomian ekonomi Mitra. Serta meningkatkan kemampuan SDM di Mitra sehingga dapat membuat yogurt secara mandiri. Oleh sebab itu maka sesuai dengan prioritas kebutuhan maka ditawarkan beberapa solusi yang terhadap permasalah yang dihadapi Mitra yakni: merancang dan membuat incubator fermentasi susu serta memberikan workshop terkait dengan komponen, cara kerja, dan perawatan inkubator tersebut serta pemasaran dari hasil produksi yang lebih luas.

Sehingga dengan alat ini dapat membantu masyarakat untuk meningkatkan pendapatan melalui penguasaan ipteks untuk meningkatkan nilai jual susu dan menghidupkan ekonomi mandiri, yaitu dengan jalan meningkatkan produktivitas sapi perah dan memberikan nilai tambah susu sapi menjadi bahan olahan yaitu yogurt. Target dari kegiatan ini adalah meringankan beban masyarakat Licin Banyuwangi melalui perbaikan manajemen pemeliharaan ternak dan meningkatkan produktivitas sapi perah, menghasilkan produk olahan dari susu sapi dengan nilai ekonomi yang lebih tinggi, menciptakan industri skala kecil.

Berdasarkan analisa, kebutuhan dan kondisi yang ada, kegiatan pengabdian yang diusulkan ini memiliki beberapa tujuan: 
- Membuat Inkubator fermentasi susu yang dapat menghasilkan yogurt yang berkualitas. Yogurt yang memiliki rasa, tekstur, aroma dan warna yang konsisten melalui proses pembuatan yang lebih efektif, efisien dan kapasitas produksi yang lebih tinggi.

- Mitra dapat memproduksi dan memasarkan yogurt secara mandiri dan berkesinambungan dengan target pemasaran yang lebih luas.

\section{B. Target Luaran}

Target utama pelaksanaan kegiatan Pengabdian Kepada Masyarakat ini adalah agar kelompok ternak mitra dapat memproduksi yoghurt secara mandiri dengan menggunakan teknologi yang inovatif kemudian mitra dapat mengemas dan memberikan label pada yoghurt tersebut, dengan ini maka mitra dapat meningkatkan prduktifitasnya.

\section{METODE PELAKSANAAN}

Untuk mencapai target yang diharapkan, maka dalam pelaksanaan pengabdian ini melibatkan beberapa pihak, yaitu: Mitra, Pengusul dan Pusat Penelitian dan Pengabdian Masyarakat (P3M) Politeknik Negeri Banyuwangi. Strategi yang dilakukan dalam kegiatan ini yaitu dengan cara meningkatkan produk dari susu melalui aplikasi teknologi modern dalam proses pembuatan yogurt. Kemudian memberikan pembekalan pelatihan, penyuluhan dan pendampingan. Berdasarkan masalah yang dihadapi mitra, dilakukan beberapa kegiatan sebagai solusi permasalahan dimana pelaksanaannya diuraikan sebagai berikut:

\section{A. Identifikasi Kebutuhan}

Tahap analisa kebutuhan merupakan suatu tahapan dimana proses pengumpulan data yang meliputi standar suhu ruangan yang terdapat didalam inkubator, tahapan dari pembuatan yoghurt dan juga tentang mengenai penelitian yang terkait dengan suatu proses pengendalian suhu dan pemantau derajat keasaman pada perangkat inkubator pembuatan yoghurt. Pada tahapan ini dilakukan dengan cara wawancara, survey ke peternakan "Ijen Makmur" dan berkoordinasi dengan Program Studi Teknik Pengolahan Hasil Ternak dan studi literature. Dari proses identifikasi ini akan didapatkan suatu perancangan desain yang baru dengan melakukan pembaharuan yang lebih baik untuk memecahkan permasalahan pada pembuatan yoghurt, agar alat yang dibuat berfungsi lebih efisien dari alat yang digunakan sebelumnya

\section{B. Perancangan Perangkat}

Pada tahap perancangan perangkat ini bertujuan agar bentuk dari suatu perangkat inkubator pembuatan yoghurt yang akan dibuat dapat berjalan dengan baik dan sesuai dengan kebutuhan. Proses yang dilakukan pada tahapan ini adalah merancang desain dimensi fisik bentuk perangkat pengendali suhu dan pemantau derajat keasaman pada inkubator pembuatan yoghurt yaitu pada gambar pada saat pembuatan dimensi fisik perangkat inkubator dapat dilakukan perubahan ukuran menyesuaikan kondisi perancangan inkubator beserta komponen elektronikanya. Selain itu juga akan dilakukan suatu desain elektronika dengan spesifikasi kegunaan yang mana berfungsi sebagai pegendali dari perangkat pengontrol suhu dan pemantau derajat keasaman pada inkubator pembuatan yoghurt semiotomatis.

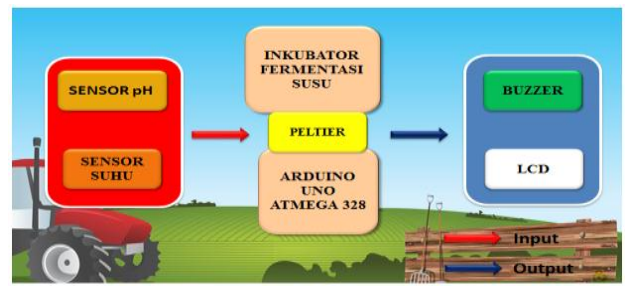

Gambar 2. Spesifikasi Perangkat Inkubator

Peltier sebagai penghangat dan pendingin ruangan didalam inkubator fermentasi susu. Sensor $\mathrm{pH}$ ditempatkan pada dasar wadah tempat fermentasi susu didalam inkubator. Sensor suhu sebagai pendeteksi suhu sebagai acuan untuk menghidupkan dan mematikan penghangat serta pendingin didalam ruangan inkubator secara otomatis. LCD untuk menampilkan waktu yang berjalan saat proses fermentasi susu, nilai suhu didalam ruangan inkubator, menampilkan derajat keasaman didalam wadah tempat fermentasi susupada saat proses pembuatan yoghurt.

Arduino dihubungkan dengan sensor suhu dalam ruangan inkubator dan modul relay yang sudah terhubung dengan penghangat dan pendingin ruangan yang akan bekerja secara otomatis ketika proses fermentasi susu berjalan dan pendingin ruangan akan bekerja otomatis ketika proses fermentasi selesai. Secara keseluruhan perangkat tersebut berjalan secara semi-otomatis. Dengan proses fermentasi susu akan ditampilkan waktu, suhu dan $\mathrm{pH}$ melalui LCD. Kemudian mesin inkubator akan bekerja secara otomatis melakukan tugasnya agar mempermudah pembuatan yoghurt.

\section{HASIL DAN PEMBAHASAN}

Pada rancang bangun perangkat keras yang telah dibuat terdiri dari beberapa bagian yang saling berkaitan untuk melakukan proses pembuatan yoghurt. Pada body inkubator dibuat menggunakan bahan akrilik dengan ketebalan $5 \mathrm{~mm}$ seperti pada gambar di bawah ini. 


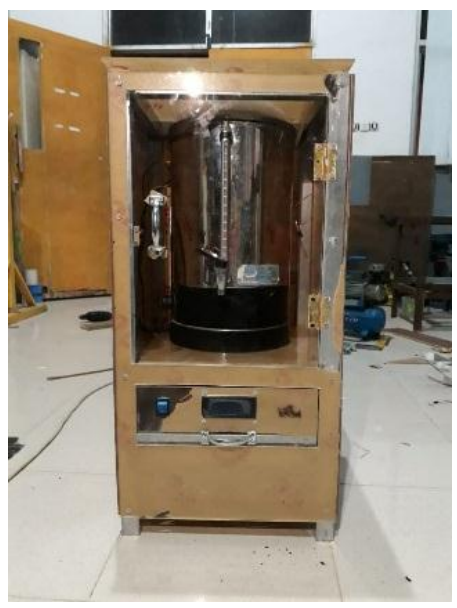

Gambar 3. Inkubator Fermentasi yang Dibangun

Komponen utama untuk mengendalikan inkubator ini adalah Arduino yang dihubungkan pada driver relay. Relay ini yang digunakan sebagai saklar mematikan dan menyalakan pemanas dan pendingin yang terdapat dalam inkubator. Modul pemanas dan pendingin didalam inkubator yang terhubung dengan relay akan nyala (on) ketika suhu dibawah $40^{\circ} \mathrm{C}$. dan akan padam (off) ketika suhu sudah stabil antara $40^{\circ} \mathrm{C}-45^{\circ} \mathrm{C}$.

Tabung inkubator ini menggunakan sensor suhu dan sensor $\mathrm{pH}$ untuk memperoleh informasi yang dibutuhkan pengendali di dalam melakukan proses fermentasi. Tabung tempat fermentasi menampung maksimal 16 liter susu. Didalam tabung fermentasi terdapat sensor $\mathrm{pH}$ yang digunakan untuk memantau apakah yoghurt sudah terbentuk atau tidak dan sedangkan sensor suhu digunakan untuk mempertahankan suhu sesusai dengan yang diharapkan.

Sebelum diterapkan alat ini diuji untuk mengetahui keakurasian pembacaan suhu pada tabung dan keakurasian pembacaan PH pada cairan susu. Untuk pengujian keakurasian sensor PH digunakan kertas lakmus untuk membandingkan dengan hasil pembacaan sensor. Pengujian dilakukan dengan larutan yang berbeda yaitu larutan dengan sifat netral, basa, dan asam. Nilai dari uji coba menggunakan kertas lakmus dan sensor $\mathrm{pH}$ juga disajikan pada grafik uji coba dengan batas nilai $\mathrm{pH}$ minimal untuk yoghurt adalah 3.5 dan maksimal adalah 4.5.

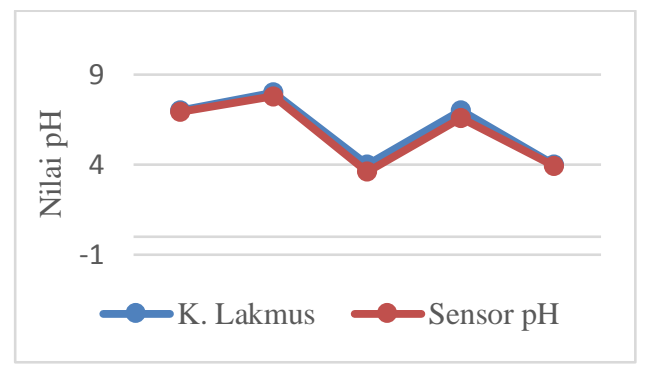

Gambar 4. Grafik Uji Coba Nilai PH

Pada pengujian nilai sensor suhu ini dilakukan menggunakan thermometer sebagai nilai pembanding dari sensor suhu dengan mengujian pada kondisi suhu yang berbeda. Pada pengujian sensor suhu dilakukan didalam ruang inkubator dengan ketentuan suhu normal atau suhu minimal yang digunakan untuk proses fermentasi adalah lebih besar dari $40{ }^{\circ} \mathrm{C}$. Sedangkan suhu panas atau suhu maksimal pada proses fermentasi adalah lebih dari $80^{\circ} \mathrm{C}$ dan untuk suhu dingin pada saat proses proses fermentasi yaitu lebih kecil dari $28^{\circ} \mathrm{C}$.

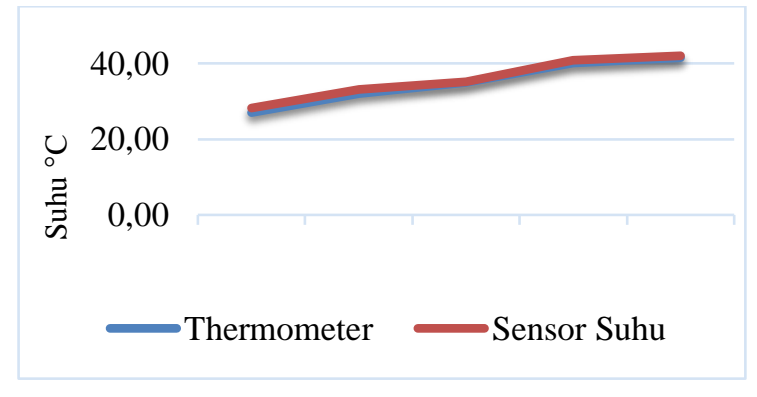

Gambar 5. Grafik hasil percobaan sensor suhu

Setelah dilakukan pengujian sensor maka dilnjutkan dengan pengujian system secara keseluruhan. Yaitu untuk mengetahui seberapa efektif waktu yang dibutuhkan system untuk melakukan fermentasi susu. Pengujian fermentasi dibuat dengan menggunakan susu sebanyak 5 liter dan didapatkan hasil yaitu rata-rata waktu yang dibutuhkan untuk menurunkan suhu sekitar dari $80^{\circ} \mathrm{C}$ ke $40^{\circ} \mathrm{C}$ adalah 48.8 menit. Sedangkan untuk proses pasteurisasi tergantung dari pemberian bakteri dan banyaknya susu yang akan difermentasi.
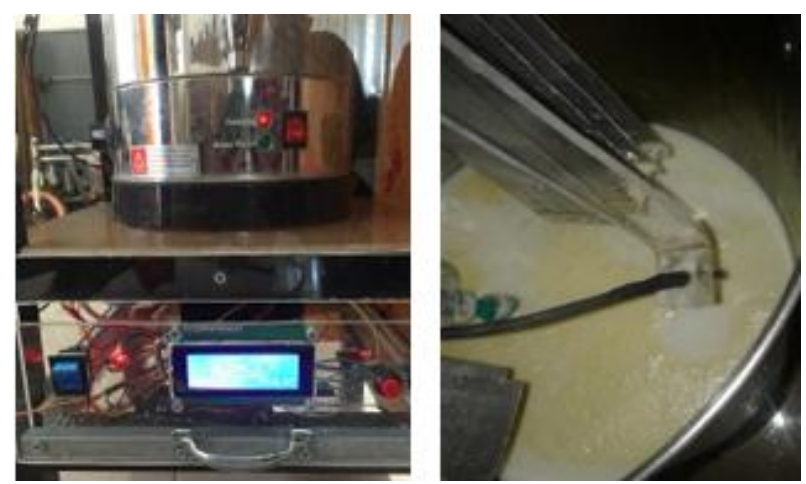

Gambar 6. Proses pembuatan yoghurt

Setelah proses fermentasi selesai maka yoghurt akan segera didinginkan untuk menjaga agar yoghurt tidak rusak. Di dalam kegiatan pengabdian ini, yoghurt yang telah matang akan dituang pada kemasan yang telah diberi label sesuai dengan nama kelompok ternak yaitu "Ijen Makmur" seperti yang ditunjukkan pada gambar di bawah ini. 


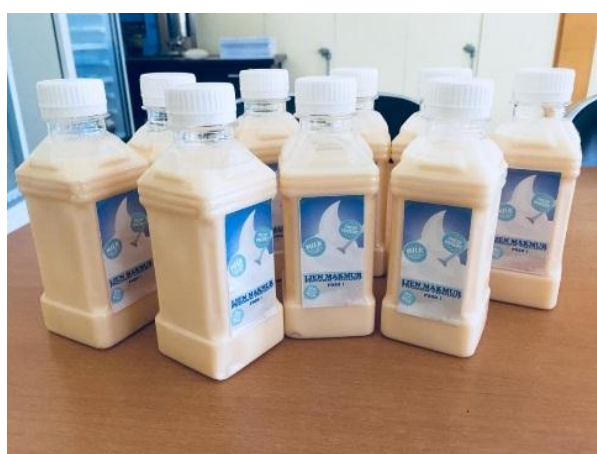

Gambar 7. Yoghurt setelah dikemas

Setelah melalui rangkaian pengujian dan percobaan, maka teknologi inkubator susu ini diserahkan kepada mitra berikut dengan cara pengoperasian, pengetahuan terkait dengan yoghurt dan lemari pendingin untuk menyimpan yoghurt yang sudah matang. Dalam kegiatan ini juga dihadiri oleh ketua Unit Penelitian dan Pengabdian Kepada Masyarakat Politeknik Negeri Banyuwangi sebagai saksi dalam pelaksanaan serah terima semua produk hasil kegiatan pengabdian ke Mitra.

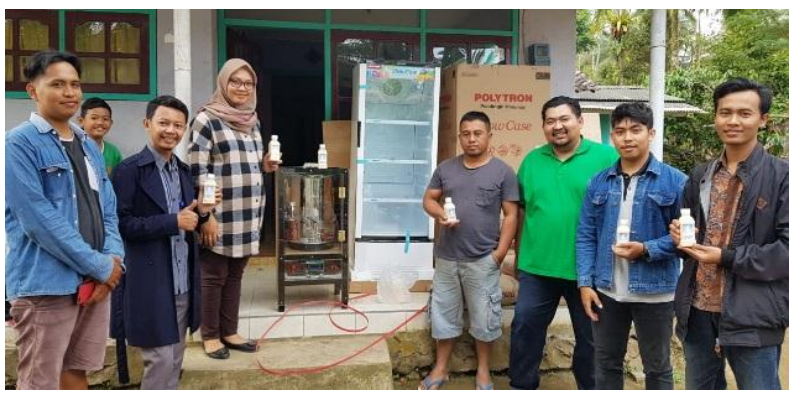

Gambar 8. Penyerahan produk pengabdian ke Mitra

\section{KESIMPULAN}

Berdasarkan hasil pelaksanaan kegiatan pengabdian kepada masyarakat dalam pembuatan yoghurt menggunakan inkubator susu ini didapatkan beberapa kesimpulan diataranya adalah:

- Kegiatan pengabdian ini memberikan dampak positif dan menghadirkan solusi bagi mitra untuk lebih produktif di dalam mengolah susu menjadi yoghurt yang dapat mereka produksi secara mandiri ataupun kelompok

- Teknologi yang diberikan kepada mitra dapat membantu memproduksi yoghurt lebih mudah dan lebih fleksible bila dibandingkan dengan proses produksi secara tradisional

- Indikasi kematangan dan proses pasteurisasi berjalan secara otomatis karena menggunakan sensor $\mathrm{Ph}$ dan sensor suhu.

\section{UCAPAN TERIMA KASIH}

Tim kegiatan pengabdian menyampaikan ucapan terimakasih yang sebesar-besarnya atas bantuan dan dukungan untuk terselenggaranya kegiatan ini kepada Direktorat Riset dan Pengabdian Masyarakat (DRPM), Kemenristekdikti yang telah memberikan dana untuk kegiatan ini. Dan kami juga berterimakasih kepada Politeknik Negeri Banyuwangi yang telah membantu memberikan fasilitas di dalam pengerjaan dan pengujian alat, dan yang terakhir tim juga mengucapkan terimakasih ayng sebanyakbanyaknya kepada Kelompok Ternak Ijen Makmur Kecamatan Licin Kabupaten Banyuwangi.

\section{DAFTAR PUSTAKA}

[1] Adnan, M. 1984. Kimia dan teknologi pengolahan air susu. Fakultas Teknologi Pertanian Universitas Gajah Mada. Yogyakarta.

[2] Anonimous. 1994. Kefir minuman berkhasiat. Perusahaan Minuman Kefir. Yogyakarta.

[3] Bourne, M. C. 1982. Food, texture and viscosity concept and measurement. Academic Press. London.

[4] Buckle, K. A., Edward, R. A., Fleet, G. H and Wotton, N. 1987. Food science. (Diterjemahkan oleh Purnomo dan Adiono dalam Ilmu Pangan). UI Press. Jakarta.

[5] Eckles, C. H., Combs, W. B. and Macy, H. 1990. Milk and milk product. Tata Mc Graw Hill Publishing Company. Ltd. Bombay.

[6] Fardiaz, S. 1992. Mikrobiologi pangan. Gramedia Pustaka Utama. Jakarta.

[7] Padaga, M. Ch dan Purnomo, H. 1993. Susu dan produk olahannya Fakultas Peternakan. Universitas Brawijaya. Malang.

[8] Sawitri, M.E. 1997. Memanfaatkan susu afkir menjadi makanan sehat dalam upaya menciptakan wirausaha baru di daerah sentra produksi susu di Jatim. Laporan Penelitian PPIS Universitas Brawijaya. Malang.

[9] Yitnosumarto, S. 1993. Percobaan: Perancangan, analisis dan interpretasinya. Program MIPA. Universitas Brawijaya. Malang.

[10] Marina D. 2014. Implementasi Pengendalian Suhu Pada Sistem Fermentasi Susu Dengan Kontrol Logika Fuzzy Berbasis Mikrokontroller Arduino Mega. Universitas Brawijaya Fakultas Teknik. Tugas Akhir. Malang.

[11] Soeparno. 2015. Properti dan Teknologi Produk Susu. Yogtakarta: Gadjah Mada University Press.

[12] Suprihatin. 2015. Teknologi Fermentasi. Surabaya: UNESA University Press. 